\title{
PENYULUHAN HUKUM BATAS USIA MINIMAL PERKAWINAN SETELAH PUTUSAN MK NO. 22/PUU-XV/2017 SEBAGAI UPAYA PERLINDUNGAN ANAK DARI PERKAWINAN DIBAWAH UMUR DI DESA DUKUHAGUNG KECAMATAN TIKUNG LAMONGAN
}

\author{
Enik Isnaini \\ Ilmu Hukum, Fakultas Hukum, Universitas Islam Lamongan \\ Jl. Veteran No. 53 A Lamongan \\ enikisnaini@unisla.ac.id
}

\begin{abstract}
ABSTRAK
Desa Dukuhagung adalah salah satu desa di Kecamatan Tikung Kabupaten Lamongan dengan total jumlah Penduduk 3.146 jiwa terdiri dengan luas wilayah 509,80 Ha ( 5,10 $\left.\mathrm{Km}^{2}\right)$. 1762 jiwa berpendididikan SMP /sederajat. Dengan tingkat Pendidikan yang masih dasar pengtahuan hokum tentang Batasan usia minimal perkawinan sangatlah penting untuk itu diperlukan kegiatan penyuluahan hokum di desa dukuhagung kecamatan tikung lamongan sebagai upaya perlindungan hokum anak di wilayah Lamongan ini. Penelitian ini adalah penelitian yuridis normative dengan pendekatan konseptual, pendekatan perundang-undangan diperoleh hasil Analisa bahwa Dengan kegiatan penyuluhan hokum batas usia minimal perkawianan di desa dukuhagung tikung lamongan dapat memberikan informasi kepada masyarakat bahwa bahaya perkawinan di bawah umur dan citacita luhur tujuan ideal perkawinan. Menerapkan batas usia minimal perkawinan dapat menjadi salah satu upaya perlindungan anak.
\end{abstract}

Kata Kunci : Batas Usia Anak, Perkawinan Dibawah Umur, Perlindungan Anak.

\begin{abstract}
Dukuhagung Village is one of the villages in the Tikung Subdistrict of Lamongan Regency with a total population of 3,146 people consisting of an area of $509.80 \mathrm{Ha}(5.10 \mathrm{Km} 2) .1762$ people educated in junior high school / equivalent. With the level of education that is still the basis of legal knowledge about the minimum age limit of marriage is very important, it is necessary to carry out legal activities in the village of dukuhagung, tikung lamongan sub-district as an effort to protect children's law in this Lamongan region. This research is a normative juridical study with a conceptual approach, the statutory approach is obtained. The analysis results show that with legal counseling activities the minimum age limit of marriage in the village of dukuhagung tikung lamongan can provide information to the public that the dangers of underage marriages and noble ideals of the ideal marriage goals. Applying a minimum age for marriage can be an effort to protect children.
\end{abstract}

Keywords: Age Limit of Children, Underage Marriage, Child Protection.

\section{PENDAHULUAN}

Perkawinan merupakan suatu ikatan lahir batin antara seorang laki-laki dan seorang wanita yang melahirkan keluarga sebagai salah satu unsur dalam kehidupan bermasyarakat 
dan bernegara, yang diatur oleh aturan hukum, baik hukum Islâm maupun hukum positif (negara).

Pengaturan hukum tentang perkawinan telah berlaku sama terhadap semua warga negara oleh karena itu, setiap warga negara harus patuh terhadap hukum yang berlaku, termasuk terhadap undang-undang perkawinan yang menjadi landasan untuk menciptakan kepastian hukum, baik dari sudut hukum keluarga,harta, bendadan akibat hukum suatu perkawinan."

Perkawinan adalah ikatan lahir batin atara seorang pria dengan seorang wanita sebagai suami istri dengan tujuan membentuk suatu rumah tangga yang kekal berdasarkan Ketuhana Yang Maha Esa". ${ }^{2}$ Suatu ikatan lahir batin adalah ikatan yag dapat di lihat". ${ }^{3}$ Dalam hukum perdata unsur usia memiliki peranan penting karena dikaitkan dengan kecakapan dalam bertindak dan lahirnya hak-hak tertentu". 4

Sejak di undangkan Hukum negara yang mengatur mengenai masalah perkawinan adalah Undang-undang Nomor 1 Tahun 1974 tentang Perkawinan. Untuk dapat mewujudkan tujuan perkawinan, salah satu syaratnya adalah bahwa para pihak yang akan melakukan perkawinan telah matang jiwa dan raganya. Oleh karena itu di dalam Undang-undang Nomor 1 Tahun 1974 ditentukan batas umur minimal untuk melangsungkan perkawinan. Ketentuan mengenai batas umur minimal tersebut terdapat di dalam Bab II Pasal 7 ayat (1) Undangundang Nomor 1 Tahun 1974 yang mengatakan bahwa "Perkawinan hanya diizinkan jika pihak pria sudah mencapai usia 19 tahun dan pihak wanita sudah mencapai usia 16 tahun".

Dari adanya batasan usia ini dapat ditafsirkan bahwa Undang-undang Nomor 1 Tahun 1974 tidak mengehendaki pelaksanaan perkawinan di bawah umur. Apabila ada perkawinan yang dilakukan oleh anak usia di bawah umur dalam hal ini pemerintah telah memberikan Kebijakan dalam menetapkan batas minimal usia pernikahan ini tentunya melalui proses dan berbagai pertimbangan atau yang lazim disebut sebagai dispensasi. Hal ini dimaksudkan agar kedua belah pihak benar-benar siap dan matang dari sisi fisik, psikis dan mental untuk melakukan perkawinan, karena mengigat perkawinan yang dilakukan agar kelak dapat terbina kekal abadi berdasarkan kepada Ketuhanan Yang Maha Esa sampai hayat memisahkan ke duanya serta untuk menunjang program kependudukan. Namun penyimpangan terhadap batas

\footnotetext{
${ }^{1}$ K. Wajik Saleh, Hukum Perkawinan Indonesia, (Jakarta: Ghalia Indonesia, Jakarta, 1982), hlm.3

${ }^{2}$ Indonesia, Undang-Undang tentang Perkawinan, Undang-Undang Nomor 1 Tahun 1974, LN. Nomor 12

Tahun 1975, TLN nomor 3050, Pasal 1

${ }^{3}$ Ibid, hlm. 14.

${ }^{4}$ J. Satrio, Hukum Kepribadian Bagian I Persoon Almiah cet 2, (Jakarta: Grasindo, 1998), hlm. 12
} 
usia tersebut dapat terjadi ketika ada dispensasi yang diberikan oleh pengadilan ataupun pejabat lain yang ditunjuk oleh kedua orang tua dari pihak pria maupun pihak wanita". Sesuai dengan bunyi Pasal 7 ayat (2).

Dalam hal penyimpangan terhadap ayat (1) pasal ini dapat meminta dispensasi kepada Pengadilan atau Pejabat lain yang ditunjuk oleh kedua orang tua pihak pria maupun pihak wanita." Secara mendasar, Pasal 7 ayat (2) UU Perkawinan mendorong lebih luas terjadinya perkawinan anak terutama dengan menggunakan frasa penyimpangan tanpa ada penjelasan yang lebih rigid terhadap penyimpangan tersebut. Argument terhadap ketentuan Pasal 7 ayat (1) UU Perkawinan sudah dijelaskan dengan baik, untuk itu perlu pengetatan terhadap ketentuan Pasal 7 ayat (2) terutama pengetatan frasa penyimpangan dan penghapusan frasa pejabat lain. Selain itu Ketentuan pengetatan ini diadakan ialah untuk menjaga kesehatan suami istri dan keturunan, dan karena itu dipandang perlu diterangkan batas umur untuk perkawinan dalam Undang-undang Perkawinan." 5Salah satu asas atau prinsip perkawinan yang Dengan demikian dapat mencegah terjadinya perkawinan anak dibawah umur".6

Desa Dukuhagung adalah salah satu desa di Kecamatan Tikung Kabupaten Lamongan dengan total jumlah Penduduk 3.146 jiwa terdiri dengan luas wilayah 509,80 Ha (5,10 Km2). 1762 jiwa berpendididikan SMP /sederajat. Dengan tingkat Pendidikan yang masih dasar pengtahuan hokum tentang Batasan usia minimal perkawinan sangatlah penting untuk itu diperlukan kegiatan penyuluahan hokum di desa dukuhagung kecamatan tikung lamongan sebagai upaya perlindungan hokum anak di wilayah Lamongan ini.

\footnotetext{
${ }^{5}$ CST. Kansil, Pengertian Ilmu Hukum dan Tata Hukum Indonesia, (Jakarta : Balai Pustaka, 1989), hlm.. 230

${ }^{6}$ Sudarsono, Hukum Perkawinan Nasional, cet. III , (Jakarta : Rineka Cipta, 2005), hlm. 7
} 


\section{METODE}

Penelitian yuridis normatif, yang menggunakan Pendekatan perundang-undangan (statute approach) dan Pendekatan konseptual (conceptual approach). Pendekatan perundangan-undangan (statute approach) diperlukan guna mengkaji lebih lanjut mengenai dasar hukum. Pendekatan perundang-undangan dilakukan dengan menelaah semua undangundang dan regulasi yang bersangkut paut dengan isu hukum. Dalam hal ini Undang-undang Nomor 1 Tahun 1974 tentang Perkawianan, Undang-undang Nomor 35 tahun 2014 tentang Perlindungan Anak. Putusan Mahkamah Konstitusi Putusan No. 22/PUU-XV/2017.

Dalam penelitian ini juga menggunakan pendekatan konseptual (conceptual approach), pendekatan yang beranjak dari pandangan-pandangan dan doktrin-doktrin yang berkembang didalam ilmu hukum. dengan menelaah pandangan-pandangan dan doktrin-doktrin tersebut dengan penafsiran sistematisasi terhadap bahan bahan hukum tertulis agar diperoleh hasil analisa hukum, yang dimaksud pendekatan konsep di sini adalah pendekatan dengan memahami konsep-konsep yang diajukan dalam permasalahan penelitian ini.

\section{HASIL DAN PEMBAHASAN}

\section{Batas Usia Anak}

Undang-Undang Nomor 23 Tahun 2002 tentang Perlindungan Anak. Namun seiring berjalannya waktu, pada kenyataannya undang-undang tersebut dirasa belum dapat berjalan secara efektif karena masih adanya tumpang tindih antar peraturan perundang-undangan sektoral terkait dengan definisi anak, di sisi lain maraknya kejahatan terhadap anak di tengahtengah masyarakat, salah satunya adalah kejahatan seksual yang saat ini banyak dilakukan oleh orang-orang dekat sang anak, serta belum terakomodirnya perlindungan hukum terhadap anak penyandang disabilitas. Sehingga, berdasarkan paradigma tersebut maka UndangUndang Nomor 23 Tahun 2002 tentang Perlindungan Anak yang saat ini sudah berlaku \pm (kurang lebih) 12 (dua belas) tahun akhirnya diubah dengan Undang-Undang Nomor 35 Tahun 2014 tentang Perubahan Atas Undang-Undang Nomor 23 Tahun 2002 tentang Perlindungan Anak, yang mempertegas tentang perlunya pemberatan sanksi pidana dan denda bagi pelaku kejahatan terhadap anak terutama kepada kejahatan seksual yang bertujuan untuk memberikan efek jera, serta mendorong adanya langkah konkrit untuk memulihkan kembali fisik, psikis dan sosial anak. Hal tersebut perlu dilakukan untuk mengantisipasi anak (korban kejahatan) dikemudian hari tidak menjadi pelaku kejahatan yang sama. Karena 
berdasarkan fakta yang terungkap pada saat pelaku kejahatan terhadap anak (terutama pelaku kejahatan seksual) diperiksa di persidangan, ternyata sang pelaku dulunya juga pernah mengalami (pelecehan seksual) sewaktu sang pelaku masih berusia anak, sehingga sang pelaku terobsesi untuk melakukan hal yang sama sebagaimana yang pernah dialami.

Undang-Undang Nomor 35 Tahun 2014 yang mulai efektif berlaku pertanggal 18 Oktober 2014 banyak mengalami perubahan "paradigma hukum", diantaranya memberikan tanggung jawab dan kewajiban kepada negara, pemerintah, pemerintah daerah, masyarakat, keluarga dan orang tua atau wali dalam hal penyelenggaran perlindungan anak, serta dinaikannya ketentuan pidana minimal bagi pelaku kejahatan seksual terhadap anak, serta diperkenalkannya sistem hukum baru yakni adanya hak restitusi.

Salah satu tindak kejahatan yang menjadi fenomena akhir-akhir ini adalah kekerasan seksual terhadap anak. Anak adalah anugerah tidak ternilai yang dikaruniakan oleh Tuhan kepada setiap pasangan manusia untuk dipelihara, dilindungi dan dididik. Ia adalah manusia yang mempunyai kemampuan fisik, mental dan sosial yang masih terbatas untuk mengatasi berbagai resiko dan bahaya yang dihadapinya dan secara otomatis masih bergantung pada pihak-pihak lain terutama anggota keluarga yang berperan aktif untuk melindungi dan memeliharanya.

Perlindungan terhadap hidup dan penghidupan anak ini masih menjadi tanggung jawab berbagai pihak yaitu kedua orang tuanya, keluarganya, masyarakat dan juga negara. Perlindungan ini dapat berupa pemenuhan kebutuhan sandang, pangan dan papan. Tidak hanya itu, perlindungan yang diberikan terhadap seorang anak juga dapat berupa perlindungan terhadap kondisi psikologis atau mental dari anak yaitu terutama perkembangan kejiwaannya. Artinya bahwa anak tersebut dapat berkembang dan hidup secara normal tidak hanya perkembangan fisiknya saja tetapi juga perkembangan jiwa atau psikisnya.

Usia seseorang merupakan salah satu tolok ukur dalam kajian hukum untuk menentukan kualifikasi pertanggungjawaban atas perbuatan yang dilakukannya. Oleh karena itu, batasan dalam penelitian ini lebih berorientasi dan menitik beratkan pada batasan usia dalam memberikan pengertian tentang anak. Secara umum berkembang pengertian anak secara variatif , seperti dalam Kamus Umum Bahasa Indonesia yang memberikan pengertian anak sebagai manusia yang masih kecil.7 Dalam kepustakaan lain, anak adalah keadaan

\footnotetext{
${ }^{7}$ W.J.S Poerwadarminta, Kamus Umum Bahasa Indonesia, Balai Pustaka, Batavia; 1976, h. . 735
} 
manusia normal yang masih muda usia dan sedang menentukan identitasnya serta sangat labil jiwanya, sehingga sangat mudah kena pengaruh lingkungannya.8 Secara konsepsional, dalam hukum di Indonesia, terdapat beberapa macam tentang pengertian anak.

Di Indonesia sendiri ada beberapa peraturan perundang-undangan yang mengatur tentang anak, misalnya Undang-Undang No. 11 Tahun 2012 tentang Sistem Peradilan Pidana Anak, Undang-Undang Nomor 4 tentang Kesejahteraan Anak, Undang-Undang Nomor 39 Tahun 1999 tentang Hak Asasi Manusia, Undang-Undang Nomor 23 Tahun 2002 tentang Perlindungan Anak dan Berbagai peraturan lain yang berkaitan dengan masalah anak.

Pengertian anak berdasarkan Pasal 1 butir 1 Undang-Undang Nomor 23 Tahun 2002 tentang Perlindungan Anak yaitu

"Anak adalah seseorang yang belum berusia 18 (delapan belas) tahun, termasuk anak yang masih dalam kandungan."

Sedangkan berdasarkan Pasal 1 ayat (3) UU No. 11 Tahun 2012 tentang Sistem Peradilan Pidana Anak juga menjelaskan tentang anak yang berkonflik dengan hukum, yaitu :

“Anak yang Berkonflik dengan Hukum yang selanjutnya disebut Anak adalah anak yang telah berumur 12 (dua belas) tahun, tetapi belum berumur 18 (delapan belas) tahun yang diduga melakukan tindak pidana."

Kemudian menurut Pasal 1 butir 5 Undang-Undang Nomor 39 Tahun 1999 tentang Hak Asasi Manusia, juga menjelaskan tentang pengertian anak yaitu sebagai berikut:

"Anak adalah setiap manusia yang berusia di bawah 18 (delapan belas) tahun dan belum menikah, termasuk anak yang masih dalam kandungan apabila hal tersebut demi kepentingannya."

Pengertian anak juga terdapat pada Pasal 1 Convention On The Rights of The Child, anak diartikan sebagai setiap orang dibawah usia 18 tahun, kecuali berdasarkan hukum yang berlaku terhadap anak, kedewasaan telah diperoleh sebelumnya.

Beberapa negara juga memberikan definisi seseorang dikatakan anak atau dewasa dilihat dari umur dan aktifitas atau kemampuan berpikirnya. Di negara Inggris, pertanggungjawaban pidana diberikan kepada anak berusia 10 (sepuluh) tahun tetapi tidak

\footnotetext{
${ }^{8}$ Kartini Kartono, Gangguan-Gangguan Psikhis, Sinar Baru, Bandung, 1981, h.187.
} 
untuk keikutsertaan dalam politik. Anak baru dapat ikut atau mempunyai hak politik apabila telah berusia di atas 18 (delapan belas) tahun. 9

Sedangkan bila bertitik tolak dari laporan penelitian Katayen H Cama, batas umur minimal bervariasi dari umur 7-15 tahun. Hal ini dipertegas dengan redaksional yaitu, Bahwa dalam tahun 1953 berdasarkan laporan Katayen H. Cama, Hakim pengadilan Anak Bombay, India yang mengadakan research untuk dapertamen Sosial dari Perserikatan Bangsabangsa atas permintaan Social Commison dari Economic and Social Council menyatakan, bahwa:10

- $\quad$ Di Bima, Ceylon dan Pakistan, seorang anak dibawah usia 7 tahun dianggap tidak melakukan kejahatan;

- Di Jepang, tindak pidana atau pelanggaran yang dilakukan oleh kurang dari 14 tahun tidak dapat dihukum;

- Di Filipina, anak-anak dibawah 9 tahun tidak dapat dipertanggung jawabkan secara kriminal;

- $\quad$ Di Bima Ceylon dan Pakistan, seorang anak diantara umur 7 tahun dan dibawah 12 tahun dan Filipna seorang anak di antara umur 9 tahun dan dibawah 15 tahun tidak dapat dipertanggungjawabkan atas tindak pidana yang dilakukannya, apabila ia pada waktu melakukannya belum dapat menghayati bahwa apa yang dilakukannya adalah salah.

\section{Kebijakan Hukum Batas Usia Minimal Perkawinan Setelah Putusan Mk No No. 22/Puu-Xv/2017.}

Sebagaimana telah diuraikan tentang perkawinan di bawah umur seseorang yang melakukan perkawinan terutama pada usia yang masih muda, tentu akan membawa berbagai macam dampak, seperti dampak pendidikan, kesehatan, pysikologis, biologis, perilaku seksual, dan dampak sosial;

Dampak pendidikan, bahwa seseorang yang melakukan perkawinan terutama pada usia yang masih di bawah umur,. keinginannya untuk melanjutkan sekolah lagi atau menempuh jenjang pendidikan yang lebih tinggi tidak akan tercapai atau tidak akan terwujud. Hal

\footnotetext{
${ }^{9}$ Marlina, Peradilan Pidana Anak Di Indonesia Pengembangan Konsep Diversi dan Restorative Justice , Refki Aditama, Bandung, 2009, h. 34-35.

${ }^{10}$ Lilik Mulyadi, 2005. Putusan Hakim Dalam Hukum Acara Pidana,Bandung, PT. Cipta Aditya Bakti. h. $16-17$
} 
tersebut dapat terjadi karena motivasi belajar yang dimiliki seseorang tersebut akan mulai mengendur karena banyaknya tugas yang harus mereka lakukan setelah menikah. Dengan kata lain, perkawinan di bawah umur merupakan faktor menghambat terjadinya proses pendidikan dan pembelajaran.

Dampak pysikologis, ditinjau dari sisi sosial perkawinan di bawah umur dapat mengurangi harmonisasi keluarga. Hal ini disebabkan oleh emosi yang masih labil, gejolak darah muda dan cara pikir yang belum matang. Melihat perkawinan dibawah umur dari berbagai aspeknya memang mempunyai banyak dampak negatif. Secara psikis anak juga belum siap dan mengerti tentang hubungan seks, sehingga akan menimbulkan trauma psikis berkepanjangan dalam jiwa anak yang sulit disembuhkan. Anak akan murung dan menyesali hidupnya yang berakhir pada perkawinan yang dia sendiri tidak mengerti atas putusan hidupnya. Oleh karenanya, dalam hukum perdata telah diatur bahwa pernikahan seseorang harus diatas umur 19 tahun untuk pria dan 16 tahun untuk wanita. Memang perkawinan dibawah umur dipandang oleh sebagian orang lebih banyak memberikan dampak negative.

Dampak biologis, di mana Anak secara biologis alat reproduksinya masih dalam proses menuju kematangan sehingga belum siap untuk melakukan hubungan seks dengan lawan jenisnya, apalagi jika sampai hamil kemudian melahirkan. Jika dipaksakan justru akan terjadi trauma, perobekan yang luas dan infeksi yang akan membahayakan organ reproduksinya sampai membahayakan jiwa anak.

Dampak kesehatan, perempuan yang menikah di usia dini kurang dari 15 tahun memiliki banyak resiko, sekalipun ia sudah mengalami menstruasi atau haid. Ada dua dampak medis yang ditimbulkan oleh pernikahan usia dini ini, yakni dampak pada kandungan dan kebidanannya. Penyakit kandungan yang banyak diderita wanita yang menikah usia dini, antara lain infeksi pada kandungan dan kanker mulut rahim. Hal ini terjadi karena terjadinya masa peralihan sel anak-anak ke sel dewasa yang terlalu cepat. Padahal, pada umumnya pertumbuhan sel yang tumbuh pada anak-anak baru akan berakhir pada usia 19 tahun.

Dampak sosial, Fenomena sosial ini berkaitan dengan faktor sosial budaya dalam masyarakat patriarki yang bias gender, yang menempatkan perempuan pada posisi yang rendah dan hanya dianggap pelengkap seks laki-laki saja. Kondisi ini sangat bertentangan dengan ajaran agama apapun termasuk agama Islam yang sangat menghormati perempuan. 
Kondisi ini hanya akan melestarikan budaya patriarki yang bias gender yang akan melahirkan kekerasan terhadap perempuan.

Dari uraian tersebut jelas bahwa perkawinan dibawah umur (anak) lebih banyak mudharat daripada manfaatnya. Oleh karena itu patut ditentang. Orang tua harus disadarkan untuk tidak mengizinkan menikahkan/mengawinkan anaknya dalam usia dini atau anak dan harus memahami peraturan perundang-undangan untuk melindungi anak.

Upaya penyuluhan hukum tentang batas usia minimal perkawinan setelah putusan mk yang menyatakan bahwa Pasal 7 ayat (1) Undang-Undang Nomor 1 Tahun 1974 tentang Perkawinan terhadap UUD 1945 yang berbunyi, "Perkawinan hanya diizinkan jika pihak pria sudah mencapai umur 19 (sembilan belas) tahun dan pihak wanita sudah mencapai umur 16 (enam belas) tahun." telah memberi dasar hukum bahwa "anak" yang berumur 16 dapat dinikahkan, dan dalam konteks ini lebih spesifik pada "anak perempuan" yang berumur 16 tahun. menunjukkan bahwa negara masih memperbolehkan adanya Perkawinan anak, khusus pada anak perempuan, yang mengakibatkan jaminan Hak Konstitusional berupa batas usia kawin para Pemohon untuk diperlakukan sama kedudukannya di dalam hukum telah terlanggar.

Perkawinan anak sangat mungkin mengancam dan berdampak negatif bagi anak termasuk kesehatan anak karena belum tercapainya batas kematangan ideal reproduksi anak. Tidak hanya masalah kesehatan, perkawinan yang belum melampaui batas usia anak sangat mungkin terjadinya eksploitasi anak dan meningkatnya ancaman kekerasan terhadap anak. Di atas itu semua, perkawinan anak akan menimbulkan dampak buruk terhadap pendidikan anak. Dalam batas penalaran yang wajar, apabila pendidikan anak terancam, hal demikian potensial mengancam salah satu tujuan bernegara sebagaimana termaktub dalam Pembukaan UUD 1945, yaitu mencerdaskan kehidupan bangsa akan sulit dicapai jikalau angka perkawinan anak tidak bisa dicegah sedemikian rupa. untuk meningkatkan batas usia perkawinan terkhusus perempuan telah dilakukan di beberapa daerah provinsi dan daerah kabupaten dengan tujuan untuk mencegah dan mengurangi perkawinan di bawah umur melalui pemberlakuan peraturan Kepala Daerah Kabupaten maupun Provinsi antara lain:

- Peraturan Bupati Kabupaten Gunung Kidul Nomor 30 Tahun 2015 tentang Pencegahan Perkawinan Anak.

- Peraturan Bupati Kabupaten Kulon Progo Nomor 9 Tahun 2016 tentang Pencegahan Perkawinan Anak. 
- Peraturan Gubernur Bengkulu Nomor 33 Tahun 2018 tentang Pencegahan Perkawinan Anak.

- $\quad$ Surat Edaran Gubernur Provinsi Nusa Tenggara Barat Nomor 150/1138 Tahun 2014 yang menganjurkan usia layak nikah pada umur 21 tahun baik untuk perempuan maupun laki-laki.

Upaya-upaya demikian juga berada pada titik temu dengan aneka agenda kebijakan pemerintah seperti program keluarga berencana dan generasi berencana (genre), pelaksanaan 12 (dua belas) tahun wajib belajar, pendidikan kesehatan reproduksi dan lain-lain. Demikian pula peran dinamis dari kaum muda yang mengambil peran dan memelopori demi mendorong pembuatan kebijakan dan alternatif-alternatif yang digagas dalam pendekatan upaya menyadarkan akan bahaya perkawinan di bawah umur dan cita-cita luhur tujuan ideal perkawinan.

\section{SIMPULAN}

Dengan kegiatan penyuluhan hokum batas usia minimal perkawianan di desa dukuhagung tikung lamongan dapat memberikan informasi kepada masyarakat bahwa bahaya perkawinan di bawah umur dan cita-cita luhur tujuan ideal perkawinan. Menerapkan batas usia minimal perkawinan dapat menjadi salah satu upaya perlindungan anak .

\section{DAFTAR PUSTAKA}

Fajar ND, Muti dan Yulianto Achmad. Dualisme Penelitian Hukum Normatif dan Empiris. Yogyakarta: Pustaka Pelajar, 2010

Hadikusumah, Hilman. 1990. Hukum Perkawinan Indonesia Menurut Perundangan, Hukum Adat dan Hukum Agama. Bandung: Mandar Maju,

Kansil, CST. 1989. Pengertian Ilmu Hukum dan Tata Hukum Indonesia. Jakarta: Balai Pustaka

Muchtar, Kamal. 1974. Asas-asas Hukum Islam tentang Perkawinan. Jakarta: Bulan Bintang

Satrio J. 1998. Hukum Kepribadian Bagian I Persoon Almiah cet 2. Jakarta: Grasindo

Sudarsono. 2005. Hukum Perkawinan Nasional, cet. III. Jakarta: Rineka Cipta,

Wajik, Saleh. 1982. Hukum Perkawinan Indonesia, Jakarta: Ghalia Indonesia 